Jagodics Balázs ${ }^{1}-$ Varga Ramóna ${ }^{2}-$

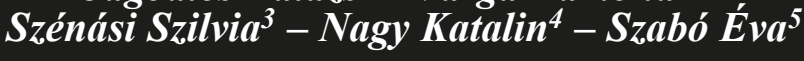

${ }^{1}$ SZTE-BTK Pszichológiai Intézet; PTE-BTK, Pszichológia Doktori Iskola

2 SZTE-BTK Pszichológiai Intézet

${ }^{3}$ SZTE-BTK Pszichológiai Intézet

${ }^{4}$ SZTE-BTK Pszichológiai Intézet

${ }^{5}$ SZTE-BTK Pszichológiai Intézet

\title{
A leterheltség és a tanulmányi motiváció összefüggése szakgimnáziumi tanulóknál
}

Az oktatási folyamatokkal kapcsolatos párbeszéd egyik központi eleme a diákok leterheltségének vizsgálata. Számos hétköznapi tapasztalat utal arra, hogy a diákok számára megterheló eleget tenni az iskolai feladatoknak. Akár a konkrét iskolai munka, akár a diákok oktatási intézményen kívüli tevékenységei kerülnek szóba, gyakran hallhatunk érveket a terhek csökkentése mellett diákoktól,

szülóktól és pedagógusoktól egyaránt. Mindemellett kutatási

beszámolók is tanúskodnak a diákok leterheltsége és ennek lehetséges káros következményei mellett (Bask és Salmela-Aro, 2013; Dobozy, 2015; Inchley és mtsai, 2016; Mayer, 2003; Salmela-Aro és mtsai, 2009). A vizsgálatok alapján az iskolai leterheltség sok helyen jelen lévó probléma, aminek elófordulását azonban nehéz számszerüsithetô formában megragadni, de kifejezhetó például a diákok óraszámával, iskolán kivüli feladataik mennyiségével vagy személyes jóllétük saját, szubjektív megitélésével. Kutatásunk célkitüzése az volt, hogy felmérjünk a szakgimnáziumi diákokat

érintố olyan tényezóket, amelyek gátolhatják vagy segithetik pszichológiai jóllétük kialakulását. Vizsgálatunkban a leterheltség

mérése mellett a tanulmányi motivációt (Deci és Ryan, 2000;

Tóth-Király és mtsai, 2017; Vallerand és mtsai, 1992) állitottuk a középpontba. A leterheltséget jelentô tényezốk feltárásához pedig a burnout-szindróma kutatásával kapcsolatban gyakran használt

követelmény-erốforrás modell (Bakker és Demerouti, 2017;

Demerouti és mtsai, 2001; Jagodics, Nagy, Szénási, Varga és Szabó, megjelenés alatt) iskolai változatát alkalmaztuk. Tanulmányunk célja, hogy bemutassa a vizsgálati eredményeket a pszichológiai leterheltség kialakulásáért felelóssé tehetó tényezók és a tanulmányi motiváció kapcsolatáról. 


\section{Az iskolai leterheltség tényezői}

A diákok iskolai jólléte az elmúlt évtizedek pedagógiai és iskolapszichológiai tárgyú kutatásainak központi témája (Konu és mtsai, 2002; Lee és Anderman, 2020). Emiatt számos olyan tényezőt sikerült feltárni, ami hozzájárul a diákok jóllétéhez és pozitív érzelmi állapotához, míg más faktorokról bebizonyosodott, hogy gátolni képesek a hatékony iskolai munkát, és összefüggésbe hozhatók a pszichológiai problémák megjelenésével. Az élettel való elégedettséget (Huebner és mtsai, 1999), a pozitív iskolai klímát (Brookover és mtsai, 1978; Thapa és mtsai, 2013), a tanulmányi motivációt (Eccles és mtsai, 1993) és a kielégítő egészségügyi állapotot (Konu, 2002) gyakran hozzák összefüggésbe az iskolai jólléttel. Ugyanakkor számos esetben nem sikerül elérni ezeket a kívánt célokat, ilyenkor az iskolai elköteleződés hiányáról (Henry és mtsai, 2012), lemorzsolódásról (Bask és Salmela-Aro, 2013; Gao és mtsai, 2019; Sorkkila és mtsai, 2019) és olyan pszichológiai problémákról beszélhetünk, mint a serdülő korosztályt jelentős arányban érintő szorongásos zavarok és a depresszió (Inchley és mtsai, 2016). Az elmúlt évtizedekben az iskolai jóllét hiányára koncentráló kutatások elkezdtek foglalkozni kiégés-szindróma (Freudenberger, 1974; Maslach és mtsai, 2001) diákok körében történő felmérésével. A vizsgálatok szerint a tanulók között is kialakulhatnak az érzelmi kimerüléssel, cinizmussal és alkalmatlanság-érzéssel jellemezhető tünetek (Maslach és mtsai, 2001; Salmela-Aro és mtsai, 2009), amely a stressznek és a leterheltségnek köszönhető, akárcsak a felnőttek munkahelyi kiégésének esetében.

A kutatások szerint az iskolai leterheltség fordított együtt járást mutat a jólléttel, vagyis a leterheltség-érzés kialakulásához hozzájáruló különböző elemek hangsúlyosabbá válása esetén csökken a diákok elégedettsége és motivációja (Kyndt és mtsai, 2011). Az iskolai leterheltséget számos tényezővel jellemezhetjük, például a számonkérések gyakoriságával, és a felkészüléshez szükséges idővel vagy a házi feladatok menynyiségével (Burnett és Fanshawe, 1997). Emellett az óraszámok is alkalmasak arra, hogy objektív szempontként szolgáljanak a leterheltség mértékének megállapítására. A hazai oktatási rendszerre jellemző állapotról az Oktatáskutató és Fejlesztő Intézet statisztikái alapján alkothatunk képet. A statisztikák szerint az általános iskola felső tagozatában hetente 28-31 óra, a középiskolában pedig 35-36 tanóra tekinthető átlagosnak (Oktatáskutató és Fejlesztő Intézet, 2019b, 2019a). A 2018-as PISA felmérés (OECD, 2019) szerint a Gazdasági Együttmüködési és Fejlesztési Szervezet (OECD) tagországai között az átlagos 35,72 órás heti terheléshez képest a magyar középiskolások átlagos óraszáma 37,48 óra. Ez ugyan átlagosnál magasabbnak tekinthető, de az OECD 36 tagállamából csak a 14. legmagasabb óraterhelést jelenti. A kötelező tanórák mennyisége mellett érdemes figyelembe venni továbbá az iskolai mindennapokkal kapcsolatos egyéb tevékenységeket is, például a korábban említett iskolán kívüli tanulást és felkészülést, illetve a házi feladatok elkészítését, amelyek tovább növelhetik az iskolai leterheltséget. Ezeknek a tényezőknek a figyelembe vételével a felmérések szerint akár a heti 50 órát is meghaladhatja a diákok tanulmányokhoz köthető tevékenységeinek mennyisége (Dobozy, 2015; Mayer, 2003).

Ugyanakkor a hasonló, objektív statisztikai adatok mellett érdemes azt is megvizsgálni, hogy a diákok szubjektív leterheltsége és jólléte hogyan írható le. Az Egészségügyi Világszervezet (WHO) Iskoláskorú Gyermekek Egészségmagatartását (HBSC) feltáró kutatásai szerint a szubjektív jóllét esetében a 15 éves korosztályban a lányok között $77 \%$, a fiúk között pedig 83\% a magas élettel való elégedettségröl beszámolók aránya Magyarországon (Inchley és mtsai, 2016). Ez az arány mindkét nem tekintetében átlag alattinak tekinthető. Az iskolához füződő viszonyt tekintve a magyar diákok átlagon felüli arányban szeretnek iskolába járni. Ez az eredmény egybevág azokkal az adatokkal, 
miszerint a magyar serdülök a második legalacsonyabb mértékben érzik úgy, hogy az iskolai munka nagy mértékü nyomást helyez rájuk. Ugyanakkor az iskolai teljesítményük szubjektív megítélése tekintetében a felmérésben részt vevő 42 ország között a legalacsonyabb elégedettségről számolnak be a magyar diákok (Inchley és mtsai, 2016). A kutatások szerint a leterheltség káros hatásainak kialakulása szempontjából a legfontosabb tényező, hogy miként észlelik a diákok a velük szemben támasztott elvárásokat, például a feladatok mennyiségének teljesíthetőségét vagy az idői nyomás mértékét (Kember, 2004). Emiatt kutatásunkban egy olyan modell használata mellett döntöttünk, amely képes a leterheltséghez hozzájáruló tényezők mellett az azokkal való megküzdést segítő erőforrások feltérképezésére is.

\section{Iskolai leterheltség a követelmények és erőforrások tükrében}

Annak érdekében, hogy a szubjektív leterheltség-érzés kialakulásának hátterében meghúzódó pszichológiai folyamatok is megragadhatók legyenek, kutatásunk során a követelmény-erőforrás modellt (Demerouti és mtsai, 2001) alkalmaztuk. A klasszikus stressz-modell szerint egy negatív, fizikai és pszichológiai kimerültséggel jellemezhetö állapot jön létre olyankor, amikor egy helyzetben a leterhelő tényezők meghaladják azoknak a belső és külső erőforrások mértékét, amelyek használhatók lennének a követelményekkel való megküzdésre (Folkman és mtsai, 1986; Lazarus és Folkman, 1984). A stresszel való megküzdés egyik központi eleme a kontroll motívuma, vagyis az az érzés, hogy a stresszt kiváltó okok vagy helyzetek irányíthatók, befolyásolhatók. Ez 2010; Karasek, 1979), amely azt feltételezi, hogy a munkahelyi stressz káros hatása nemcsak a stressz mértékéből fakad, hanem a nehézségek kezelése felett észlelt kontroll is befolyásolja. Karasek modelljét később további faktorokkal egészítették ki, létrehozva a Követelmény-Erőforrás modellt a munkahelyi stresszfolyamatok magyarázatára (Bakker és Demerouti, 2017; Demerouti és mtsai, 2001).

Az eredeti megközelítés munkahelyi környezetben vizsgálta a leterheltséget. Ez alapján azok a faktorok sorolhatók a követelmények közé, amelyek növelik a fizikai, érzelmi vagy szellemi kimerülés esélyét, ezzel hosszú távon növelve a stressz káros hatásainak 
kialakulását. A modell másik elemét az erőforrások jelentik, amelyek az akadályok leküzdésére használható minden személyes vagy környezeti tényezőt magukban foglalnak. A kutatási eredmények a követelmények számos faktorát azonosították, például a mentális igénybevételt, a munkaidő hossza okozta leterhelést, az érzelmileg megterhelö helyzeteket vagy az ellenséges munkahelyi légkört. Ezzel szemben a kontroll motívuma mellett az autonóm tervezés és döntéshozás, a személyes fejlődés lehetősége vagy a társak támogatása erőforrásnak tekinthető (Demerouti és mtsai, 2001). A követelmény-erőforrás modell tényezői jól használhatók a kiégés-szindróma kialakulásának magyarázatára, mert több vizsgálat eredménye szerint is együtt járás figyelhető meg a tényezői és a burnout tüneteinek megjelenése között (Bakker és mtsai, 2007; Brouwers és mtsai, 2011).

A modell iskolai környezetben, kifejezetten pedagógusoknál alkalmazva is rámutatott arra, hogy a követelmények pozitívan kapcsolódnak a kiégés tüneteihez, míg az erőforrások negatívan járnak együtt a burnout dimenzióival (Bottiani és mtsai, 2019; Dicke és mtsai, 2018). A követelmény-erőforrás modellel kapcsolatos kutatások szerint a munkával való elégedettséggel és a munkahely elhagyására irányuló motivációval kapcsolatban áll a követelmények alacsonyabb mértéke (Schiffinger és Braun, 2019). Emellett az is fontos eredmény, hogy az erőforrások jelenléte képes ellensúlyozni a követelmények káros hatásait azáltal, hogy erösítik a nehézségekkel való megküzdés képességét (Jagodics és Szabó, 2014; Szabó és Jagodics, 2016).

A követelmény-erőforrás modellt tehát a stressz és leterheltség következményeként kialakuló munkahelyi kiégés megértése érdekében hozták létre. Azonban a kutatások szerint a kiégés-szindróma nem csak munkahelyi környezetben értelmezhetö, hanem diákok között is (Fiorilli és mtsai, 2017; Salmela-Aro és mtsai, 2009). Emiatt az elmúlt évtizedben egyre több olyan kutatási koncepció született, amely követelmény-erőforrás modellt igyekszik adaptálni az iskolai viszonyokra annak érdekében, hogy a leterheltség pszichológiai aspektusait megragadhatóvá tegye (Cilliers és mtsai, 2017; Ouweneel és mtsai, 2011; Salmela-Aro és Upadyaya, 2014). Ezek a kutatások koncepciójukban igazodnak a követelmény-erőforrás modellhez, azonban nem rendelkeznek egységes elképzeléssel a faktorok strukturálásához. Upadyaya és Salmela-Aro (2014) kutatásában a követelményeket és az erőforrásokat is egy-egy dimenzióval, az iskolai feladatok nehézségével és a személyes fejlődés lehetőségével mérték. Más kutatások pszichológiai jellegü tanulási erőforrásokat, például az énhatékonyságot és az optimizmust használták a modell felépítésére (Ouweneel és mtsai, 2011). Az eredeti elképzeléshez legközelebb álló, komplex modellben együttesen jelennek meg a tanulmányi feladatok nehézségét és mennyiségét összegző követelmények és a társas támogatásból, valamint a fejlődési lehetőségekből álló erőforrások (Cilliers és mtsai, 2017).

Az említett kutatások eredményei megerősítik a követelmény-erőforrás modell alkalmazásának létjogosultságát az iskolai kutatások során, ugyanis az erőforrások együtt járást mutattak az iskolai jólléttel, a tanulmányi elköteleződéssel és az érzelmi kimerüléssel, míg a követelmények negatív összefüggésben állnak ezekkel a tényezőkkel (Cilliers és mtsai, 2017; Hodge és mtsai, 2019; Ouweneel és mtsai, 2011; Salmela-Aro és Upadyaya, 2014). Hazai viszonyok között mind általános, mind pedig középiskolás mintán kidolgoztak és teszteltek egy iskolai követelmény-erőforrás kérdőívet, igazodva az eredeti elképzelés komplex megközelítéséhez (Demerouti és mtsai, 2001). A faktorelemzések szerint a modell jól alkalmazható mind az általános, mind pedig a középiskolás diákok esetében, azonban eltérő módon. Az általános iskolás felmérés szerint a követelmények esetében négy faktor különíthető el (mentális munkamód leterheltsége, negatív kapcsolatok, teljesítménykényszer és konfliktusok), míg az erőforrások öt tényezőből állnak (szülők támogatása, információ és támogatás a tanároktól, visszajelzések, kontroll és személyes fejlődés; Jagodics és mtsai, megjelenés alatt). A középiskolás 
felmérés a követelmények esetében az autoritás-konfliktust, a pályaválasztási szorongást, a mentális leterhelést, a munkamódból származó kimerülést és a negatív érzelmeket azonosította, míg az erőforrások között a tanároktól és a szülőktől kapott támogatás mellett a személyes fejlődés és az autonómia jelent meg (Jagodics és mtsai, megjelenés alatt).

\section{Tanulmányi motiváció az öndeterminá- ciós elméletben}

A kutatás során a Deci és Ryan $(1985,2000)$ által kidolgozott öndeterminációs elmélet alapján vizsgáltuk a tanulmányi motivációt. Az öndeterminációs elmélet szerint az emberek viselkedését különféle motivációk vezérlik. Forrásuktól függően elkülöníthetők belső (intrinzik) és külső (extrinzik) természetű motivációk. Előbbiek közé tartoznak a tudásra, teljesítményre vagy élményekre irányuló motivációk, míg az extrinzik motivációkat legtöbbször a jutalomtól vagy büntetéstől függő külső szabályozással jellemezhetjük. Ugyanakkor a kutatási eredmények rámutattak arra, hogy a külső eredetü büntetések és jutalmak különböző mértékben belsővé is tehetők, így külső ellenőrzés vagy visszajelzés nélkül is szabályozhatják a viselkedést (Deci és Ryan, 2000; Vallerand és mtsai, 1992). Mindemellett egy bizonyos viselkedésre, például a tanulásra vonatkozó késztetések hiánya esetén leírható az amotiváció állapota is, amely mind a külső, mind pedig a belső eredetü ösztönzőerő nélküli státuszt írja le. Az öndeterminációs elmélet segítségével leírható, hogy egy személy viselkedése mennyire tulajdonítható belső és mennyiben külső eredetü hatásoknak.

A különböző motivációs tényezők az iskolai munka során is jelen vannak, hiszen míg egyes tanulókat a tantárgy iránti érdeklődés ösztönöz, addig másokat elsősorban az érdemjegyek motiválnak. A kutatási eredmények szerint a tanulmányi motiváció magasabb mértéke együtt jár az erősebb iskolai elköteleződéssel (Bolkan, 2015), a tanulással kapcsolatos pozitív érzésekkel és lelkesedéssel (Altintas és mtsai, 2020), valamint a tanulmányi teljesítménnyel (Long és mtsai, 2007). A motiváció forrásával foglalkozó tanulmányok feltárták, hogy a tanulmányi motiváció hosszú távú fenntartásával kapcsolatban elsősorban az intrinzik jellegü ösztönzők hatásosak (Garon-Carrier és mtsai, 2016). Az öndeterminációs elmélet szerint a belső motiváció két kognitív jellegü tényezőnek köszönhetően erősíthető meg: ha egy helyzetben
A különbözó motivációs tényezók az iskolai munka során is jelen vannak, hiszen mig egyes tanulókat a tantárgy iránti érdeklódés ösztönöz, addig másokat elsósorban az érdemjegyek motiválnak. A kutatási eredmények szerint a tanulmányi motiváció magasabb mértéke együtt jár az erôsebb iskolai elkötelezódéssel (Bolkan, 2015), a tanulással kapcsolatos pozitív érzésekkel és lelkesedéssel (Altintas és mtsai, 2020), valamint a tanulmányi teljesítménnyel (Long és mtsai, 2007). A motiváció forrásával foglalkozó tanulmányok feltárták, hogy a tanulmányi motiváció hosszú távú fenntartásával kapcsolatban elsôsorban az intrinzik jellegú ösztönzók hatásosak (Garon-Carrier és mtsai, 2016). Az öndeterminációs elmélet szerint a belsố motiváció két kognitív jellegú tényezônek köszönhetốn erôsithetố meg: ha egy helyzetben teljesül az autonómia és a kompetencia iránti igény (Deci és Ryan, 2000). 
teljesül az autonómia és a kompetencia iránti igény (Deci és Ryan, 2000). Ezzel szemben a külső motiváció negatív bejósló erővel bír a tanulmányi teljesítményre (Wolters és mtsai, 1996), habár a kapcsolat erőssége az érdemjegyek és az intrinzik motiváció között erösebb (Areepattamannil és mtsai, 2011).

Habár az öndeterminációs elmélet nem fedi le teljesen a tanulmányi motiváció teljes spektrumát, a kutatás tervezése során azért döntöttünk a használata mellett, mert az elmélet külső és belső ösztönző erőkből felépülő rendszerét illeszkedőnek találtuk a követelmény-erőforrás modellhez. Utóbbi tényezői között egyaránt találhatunk külső (konfliktusok, támogató környezet) és belső (személyes fejlődés, kontroll) eredetü tényezőket. Mindezek alapján mindenképpen érdemes megvizsgálni, hogy milyen tényezők hozhatók összefüggésbe a tanulmányi motiváció, elsősorban az intrinzik komponensek kialakulásával. Emellett fontos szempont szempont volt, hogy magyar nyelven elérhető és középiskolás mintán kipróbált eszközt használjunk.

\section{Célkitűzés és hipotézisek}

Kutatásunk célkitüzése az volt, hogy szakgimnáziumi képzésbe járó diákok körében felmérjük a leterheltség jellemzőit a követelmény-erőforrás modell segítségével. Emellett célul tüztük ki, hogy megvizsgáljuk a leterheltséghez füződő pszichológiai mechanizmusok összefüggéseit a tanulmányi motivációval. Feltételeztük, hogy a követelmények negatív (H1), míg az erőforrások pozitív kapcsolatban állnak a belső és külső motivációval egyaránt (H2). Harmadik hipotézisünkben feltételeztük, hogy az öndeterminációs elméletnek megfelelően a belső motivációval a kontroll, a személyes fejlődés és az autonómia faktorainak lesz a legerősebb kapcsolata (H3; Deci és Ryan, 2000). Végül negyedik hipotézisünk az amotiváció és a leterheltség kapcsolatára vonatkozott, amelyek között pozitív együtt járást vártunk $(\mathrm{H} 4)$.

\section{Módszerek}

\section{Minta és eljárás}

Kutatásunk alapját egy szakgimnáziumi tanulók részvételével zajló kérdőíves kutatás adta. Az adatfelvételben összesen 329 diák vett részt (214 lány és 115 fiú, átlagéletkor $=16,9$ év, szórás $=1,38$ év), akik közül 112-en kilencedik, 42-en tizedik, 102-en tizenegyedik és 73-an tizenkettedik évfolyamba jártak. A tanulók az iskolában, osztályfőnöki órán, számítógépteremben, online felületen válaszoltak a kérdésekre. Az adatfelvétel kezdete előtt a részvételre felkért oktatási intézmény vezetőjét informáltuk a kutatás részleteiről, és beleegyezését kértük a vizsgálat lefolytatásába. A diákok szüleit passzív beleegyező nyilatkozat formájában tájékoztattuk, illetve kértük engedélyüket a vizsgálat elvégzéséhez. Azok a diákok, akiknek a szülei nem engedélyezték számukra a kutatásban való részvételt, nem töltötték ki a kérdőíveket. A vizsgálatban az alábbi demográfiai adatokat kértük a diákoktól: nem, életkor és évfolyam. A kutatáshoz való csatlakozás önkéntes volt a kitöltők részéről, és a résztvevők a válaszadás megkezdése előtt részletes írásbeli tájékoztatást kaptak az adatfelvétel módszeréről és céljáról, valamint lehetőségük volt feltenni a kérdéseiket. A vizsgálat résztvevői nem részesültek ellenszolgáltatásban a részvételért, és a kitöltést bármikor következmények nélkül megszakíthatták. A kutatás folyamatát és a használt módszereket a Pszichológiai Kutatások Egyesült Etikai Bíráló Bizottsága előzetesen jóváhagyta (referenciaszám: 2017/122). 


\section{Mérőeszközök}

\section{Az Iskolai Követelmény-Erőforrás Kérdöív}

Az Iskolai Követelmény-Erőforrás Kérdőív középiskolás változata (Jagodics és mtsai, megjelenés alatt) korábbi, munkahelyi vonatkozású skálák alapján lett kifejlesztve (Demerouti és mtsai, 2001; Szabó és Jagodics, 2016). A kitöltők hatfokozatú Likertskálán jelölhették válaszaikat $(1=$,Egyáltalán nem jellemző rám”; $6=$ „,Teljesen jellemző rám”). A vizsgálatban használt változat összesen 37 tételből állt. A kérdőív két skálából és összesen tíz alskálából áll. A követelmények skálához az alábbi öt alskála tartozik: autoritás-konfliktus, pályaválasztási szorongás, mentális leterhelés, munkamódból származó kimerülés és negatív érzelmek. Az erőforrás-skála szintén öt alskálából épül fel: a tanároktól, illetve a szülőktől kapott támogatás, kontroll, személyes fejlődés és autonómia. A kérdőív megerősítő faktorelemzés alapján stabil szerkezettel rendelkezik, és az alskálák belső megbízhatóságának mutatói is kedvezőek (ld. 1. táblázat).

\section{A Tanulmányi Motiváció Kérdőív}

Az adatfelvétel során a tanulmányi motiváció mérésére az eredetileg Vallerand és munkatársai (1992) által kidolgozott kérdőív magyar változatát használtuk (Tóth-Király, Orosz, Dombi, Jagodics, Farkas és Amoura, 2017). A Tanulmányi Motiváció Kérdőív összesen 28 tételből áll, amelyek három motivációs komponenst különítenek el: intrinzik és extrinzik motivációt, valamint amotivációt. Az intrinzik motiváció skála további három alskálára bontható (tudásra, élményekre és teljesítményre irányuló motiváció), csakúgy, mint az extrinzik motiváció skála (külső szabályozás, belsővé tett szabályozás, azonosult szabályozás). A kitöltők hatfokozatú Likert-skálán jelölhették válaszaikat ( 1 = „Egyáltalán nem jellemző rám”; 6 = „Teljesen jellemző rám”). A kérdőív a megerősítő faktorelemzés szerint stabil szerkezettel rendelkezik, illetve az alskálái jó belső megbízhatósági mutatókkal jellemezhetőek (lásd. 1. táblázat).

\section{Eredmények}

\section{Elözetes elemzések és leiró statisztika}

A statisztikai elemzésekhez az IBM SPSS 24.0, illetve a Jamovi 1.0.0.0 (The Jamovi Project, 2019) programcsomagokat használtuk.

A változók normáleloszlását a csúcsosság és ferdeség értékek segítségével ellenőriztük, ahol a $|2,58|$-as határértéknél alacsonyabb tartományt fogadtuk el a normáleloszlás kritériumaként (Ghasemi és Zahediasl, 2012). Az elemzésben szereplő változók mindegyike esetében teljesült a normáleloszlás kritériuma, így a hipotézisek ellenőrzéséhez parametrikus statisztikai próbákat alkalmaztunk.

Az eredmények bemutatását a vizsgált változókhoz kapcsolódó leíró statisztikai elemzésekkel kezdjük (1. számú táblázat). Az Iskolai Követelmény-Erőforrás Kérdőív skálái szerint a kitöltő diákok esetében erőforrás-túlsúlyról beszélhetünk. Ez a leterheltség mutató alapján állapítható meg, mely a követelmények és az erőforrások átlagpontszámok különbségeként számítható ki. Tekintve, hogy az átlagpontszám $(\mathrm{M}=-0,45)$ a negatív tartományban helyezkedik el, ezért összességében az erőforrásokat magasabbra értékelték a diákok a leterheltséget nyújtó tényezőknél. Az elemzések alapján a diákok 61\%-a helyezkedik el az erőforrás-túlsúllyal jellemezhető tartományban, míg 39\%-uk 
esetében beszélhetünk leterheltségről abban az értelemben, hogy szubjektív értékelésük alapján a követelmények mértéke meghaladja a rendelkezésre álló erőforrásokét.

Az egyes alskálák az erőforrások közül a legmagasabbra a szülői támogatást értékelték a diákok $(M=4,92)$, melyet a kontroll $(M=4,22)$ és a tanári támogatás követett $(\mathrm{M}=4,04)$. Az erőforrások közül a személyes fejlődés lehetősége $(\mathrm{M}=3,93)$ és az autonómia $(\mathrm{M}=3,57)$ van tehát jelen alacsonyabb mértékben a diákok életében. A követelmények esetében a legmagasabb átlagot a mentális leterheltség $(M=4,08)$ esetében értek el a diákok, melyet a negatív érzelmek $(\mathrm{M}=3,84)$ és a munkamódból származó követelmények $(\mathrm{M}=3,8)$ követtek. Legalacsonyabb mértékben az autoritás-konfliktus $(\mathrm{M}=3,49)$ és a pályaválasztási szorongás $(\mathrm{M}=3,17)$ jelenik meg a tanulók értékelései alapján.

A Tanulmányi Motiváció Kérdőív alskálái esetében az amotiváció értéke volt a legalacsonyabb $(\mathrm{M}=2,83)$. Az extrinzik motiváció esetében erősnek bizonyult a külső szabályozás $(M=5,43)$, melyet az azonosult szabályozás $(M=4,45)$ és a belső szabályozás $(\mathrm{M}=3,94)$ követett. Az intrinzik motiváció esetében a tudásra vonatkozó ösztönzők $(\mathrm{M}=4,31)$ voltak a leghangsúlyosabbak, melyet a teljesítmény $(\mathrm{M}=3,99)$ és az élmények átélése $(\mathrm{M}=2,96)$ követett.

1. táblázat. Az Iskolai Követelmény-Erőforrás Kérdőív (6 fokú skála) és a Tanulmányi Motiváció Kérdöiv (7 fokú skála) alskáláinak leíró statisztikai elemzése.

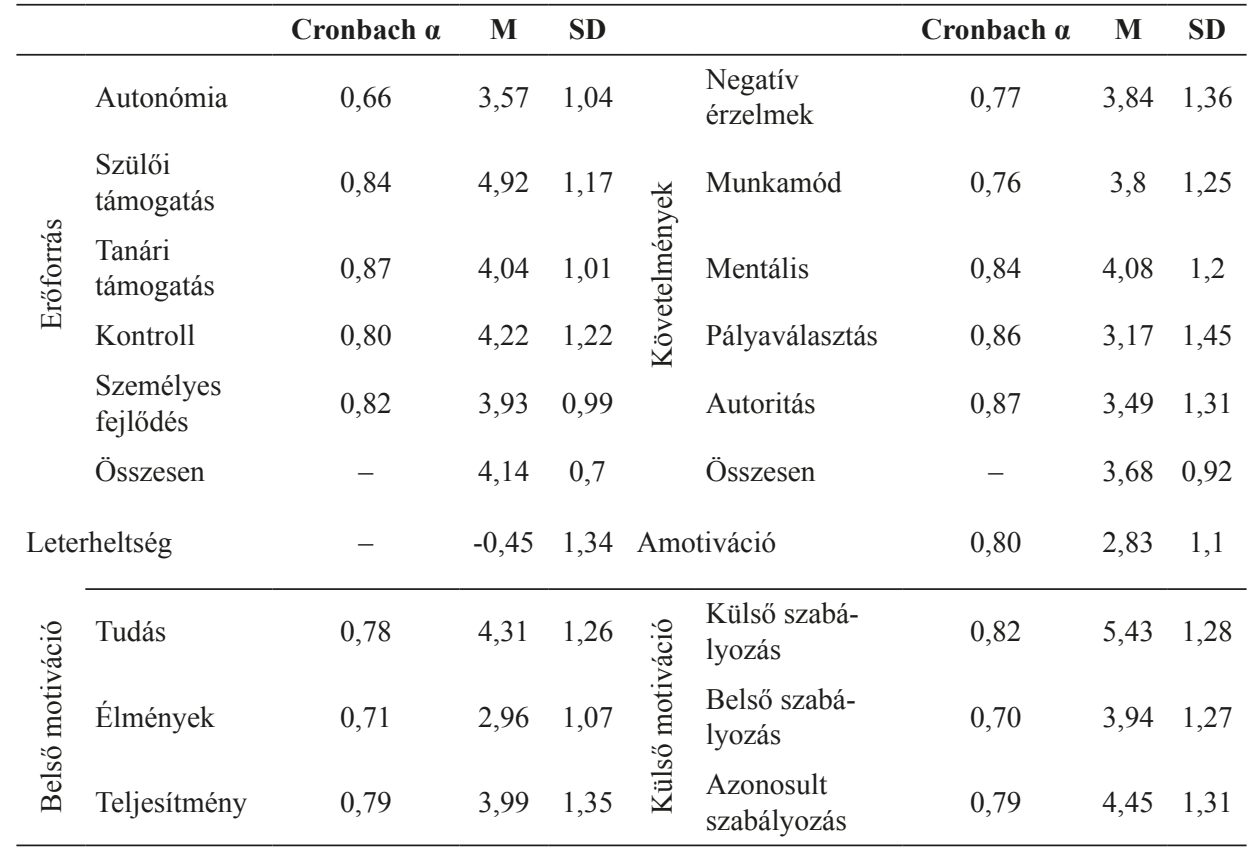

\section{A követelmény-eröforrás modell elemeinek kapcsolata a tanulmányi motivációval}

A változók együtt járására vonatkozó hipotéziseket Pearson-féle korrelációelemzéssel vizsgáltuk. A követelmények és a motivációs jellemzők kapcsolatára vonatkozó hipotézisünk csak részben igazolódott be (H1), mert a skálák között többségében nem-szignifikáns vagy nagyon gyenge együtt járást tárt fel a statisztikai elemzés. Az eredmények alapján úgy tekinthető, hogy az intrinzik és extrinzik motivációs típusok, valamint a 
követelmények kapcsolatára vonatkozó hipotézisünket nem támasztották alá az elemzések. Egyedül az amotivációval kapcsolatban igazolták az eredmények az elöfeltevést, mely gyenge pozitív együtt járást mutatott a követelmény alskálák többségével, legerősebben az autoritás konfliktussal $(\mathrm{r}=0,35 ; \mathrm{p}<0,001)$. Az erőforrások és a motiváció közötti kapcsolat elöfeltevésünknek megfelelö alakult $(\mathrm{H} 2)$, a változók között többségében szignifikáns pozitív együtt járást találtunk. Az egyes erőforrástípusok között azonban jelentős különbség volt a kapcsolat erősségében. A tanulmányi motiváció a tanári támogatás mértékével, illetve a személyes fejlődés lehetőségével korrelált a legnagyobb mértékben. Utóbbi részben erősítette meg az intrinzik motivációval kapcsolatos hipotézisünket (H3). Ugyanis a kontroll és a személyes fejlődés erőforrásokkal ellentétben az autonómia alskála nem mutatott statisztikailag szignifikáns összefüggést az intrinzik és extrinzik motiváció mértékével, igaz, az amotiváció skálával kapcsolatban látható gyenge negatív együtt járás megfelelt az előfeltevéseknek $(\mathrm{r}=-0,227 ; \mathrm{p}<0,001)$. Az amotiváció az előfeltevésünknek (H4) megfelelően negatív kapcsolatban volt az erőforrásokkal, és pozitív együtt járást mutatott a követelményekkel, illetve a leterheltség mutatóval is.

2. táblázat. A változók közötti együtt járások Pearson-féle korrelációelemzés alapján. $*_{p}<0,05 ; * *_{p}<0,001$.

\begin{tabular}{|c|c|c|c|c|c|c|c|c|}
\hline & \multicolumn{3}{|c|}{ Intrinzik motiváció } & \multicolumn{3}{|c|}{ Extrinzik motiváció } & \multirow[b]{2}{*}{ Amotiváció } \\
\hline & & Tudás & Élmény & $\begin{array}{c}\text { Teljesít- } \\
\text { mény }\end{array}$ & Külső & $\begin{array}{c}\text { Belsővé } \\
\text { tett }\end{array}$ & Azonosult & \\
\hline \multirow{6}{*}{ 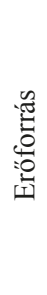 } & Autonómia & n.sz. & n.sz. & n.sz. & n.sz. & n.sz. & n.sz. &,$- 227 * *$ \\
\hline & Szülői támogatás &, $221 * *$ & n.sz. &, $168^{*}$ &, $258 * *$ &, $217 * *$ &, $168 *$ &,$- 169 *$ \\
\hline & Tanári támogatás &, $446^{* *}$ &, $178 * *$ &, $375 * *$ &, $267 * *$ &, $444 * *$ &, $337 * *$ &,$- 195 * *$ \\
\hline & Kontroll &, $325 * *$ & n.sz. &, $244 * *$ &, $21 * *$ &, $334 * *$ &, $23 * *$ & n.sz. \\
\hline & Személyes fejlődés &, $603 * *$ &, $119 *$ &, $506 * *$ &, $413 * *$ &, $633 * *$ &, $508 * *$ &,$- 358 * *$ \\
\hline & Összesen &, $511 * *$ & n.sz. &, $413 * *$ &, $357 * *$ &, $522 * *$ &, $405^{* *}$ &,$- 312 * *$ \\
\hline \multirow{6}{*}{ 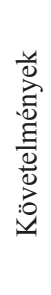 } & Negatív érzelmek & n.sz. & n.sz. & n.sz. &, $122 *$ & n.sz. & n.sz. &, $149^{*}$ \\
\hline & Munkamód &,$- 144 *$ & n.sz. & n.sz. & n.sz. & n.sz & n.sz. &, $225 * *$ \\
\hline & Mentális & n.sz. & n.sz & n.sz. &, $184 * *$ & n.sz. & n.sz. & n.sz. \\
\hline & Pályaválasztás & n.sz. & n.sz & n.sz & n.sz. & n.sz & n.sz &, $199 * *$ \\
\hline & Autoritás &,$- 162 *$ & n.sz & n.sz & n.sz &,$- 178 * *$ & n.sz. &, $35 * *$ \\
\hline & Összesen & n.sz. & n.sz & n.sz &, $114^{*}$ & n.sz. & $217^{*}$ &, $274 * *$ \\
\hline \multicolumn{2}{|c|}{ Leterheltség } &,$- 334 * *$ & n.sz &,$- 219 * *$ & n.sz. &,$- 321 * *$ &,$- 191 * *$ &, $352 * *$ \\
\hline
\end{tabular}

\section{Megvitatás}

Kutatásunknak két fó célkitüzése volt: egyrészt a szakgimnáziumban tanuló diákok leterheltségének felmérése a követelmény-eröforrás modell (Demerouti és mtsai, 2001) segítségével, másrészt pedig az említett faktorok tanulmányi motivációval való kapcsolatának feltárása. A követelmény-eröforrás modell tényezőivel kapcsolatos leíró statisztikai elemzések érdekes tanulságokkal szolgálnak a diákokat érő iskolai hatások összefüggésében. A követelmények közül a mentális leterheltség jelent meg a leginkább a diákok értékelésében, ami utal arra, hogy sok esetben találkoznak fokozott kihívást jelentő feladatokkal az iskolában. Ehhez minden bizonnyal hozzájárul a heti óraszám 
(Oktatáskutató és Fejlesztő Intézet, 2019a) és az iskolán kívüli tevékenységek magas száma is (Dobozy, 2015). Mindemellett pedig megemlíthető, hogy az észlelt leterheltséget az is növelheti, hogy a diákoknak nem egyegy témában elmélyedve kell eredményre jutniuk az iskolában, hanem változatos tantárgyakkal találkoznak. A különböző területek egyrészt eltérő készségeket igényelnek, másrészt a velük való foglalkozáshoz szükség van rugalmas figyelmi váltásokra is. A mentális leterheltséghez kapcsolódhatnak a munkamóddal összefüggő tényezők is, például a feladatokkal kapcsolatos idői nyomás, a több tantárgyból való párhuzamos felkészülés elvárása is.

A leterheltséghez az adatok szerint hozzájárulnak továbbá a negatív érzelmek is. Ennek egyik oka a kortársakkal való kapcsolatban megjelenő konfliktusok között kereshetö, hiszen a bullying/iskolai zaklatás sok esetben okoz problémát a diákoknak a mindennapokban, nem csak áldozatként, de szemlélö félként is (Gaffney és mtsai, 2019; Salmivalli és Voeten, 2004; Várnai és mtsai, 2018). Emellett pedig a pedagógusokkal való kapcsolat is hozzájárulhat a konfliktusok megéléséhez, akár a fegyelmezési problémákkal, akár az értékeléssel kapcsolatban. A kutatási eredmények szerint a diákok érzékenyek a tanár nonverbális kommunikációjára, érzelmi állapotára és motiváltságára, és ezek hiánya az érdeklődés csökkenéséhez vezethet (Evers és mtsai, 2004; Tatar és Yahav, 1999; Zhang és Sapp, 2009). Ugyanakkor az eredményekből feltételezhető, hogy elsősorban a kortárskapcsolatok járulnak hozzá az iskola leterheltséghez, legalábbis az autoritás-konfliktus alskála alacsonyabb átlagpontszáma arra enged következtetni, hogy a kifejezetten pedagógusokkal kapcsolatban megélt nézeteltérések hatása kisebb. A követelmények közül a pályaválasztási szorongás bizonyult a legalacsonyabb mértékűnek. Ezt magyarázhatja, hogy a diákok életkori összetétele vegyes volt, vagyis kilencedik és tizedik évfolyamos diákok is részt vettek a kitöltésben, estükben pedig az iskola befejezése távolibbnak tünhet, mint a végzős tanulók között.

Az erőforrások esetében a szülői támogatás esetében látható a legmagasabb átlagpontszám. Ez arra utal, hogy a serdülőkorban jellemzően konfliktusos szülő-gyermek
Az eróforrások esetében a szülöi támogatás esetében látható a legmagasabb átlagpontszám. Ez arra utal, hogy a serdülókorban jellemzóen konfliktusos szüló-gyermek kapcsolat összességében jelentốs pozitív támogatást ad a diákoknak, amely az

iskolai életben is fontos számukra. Szintén jelentôsnek tekinthetố a kontroll szerepe, ami a stresszel való megküzdéssel kapcsolatos modellekben is

központi helyet foglal el (Bakker és mtsai, 2007; Folkman és mtsai, 1986; Karasek, 1979). Ez azt mutatja, hogy a diákok számára fontosak a döntési lehetóségek a tanulási folyamat személyre szabása érdekében. A tanári támogatással kapcsolatos eredmények egybevágnak az affektív-érzelmi tanulási tényezókkel (Picard és mtsai, 2004), illetve az észlelt tanári kiégéssel kapcsolatos korábbi kutatási eredményekkel (Tatar és Yahav, 1999; Zhang és Sapp, 2009). Ez alapján a pedagógusi munka hatékonyabbá tétele során kiemelt szerepe lehet a tanár-diák kapcsolatok alakitásának, ami a leterheltség észlelt mértékének csökkenését is segitheti. 
kapcsolat összességében jelentős pozitív támogatást ad a diákoknak, amely az iskolai életben is fontos számukra. Szintén jelentősnek tekinthető a kontroll szerepe, ami a stresszel való megküzdéssel kapcsolatos modellekben is központi helyet foglal el (Bakker és mtsai, 2007; Folkman és mtsai, 1986; Karasek, 1979). Ez azt mutatja, hogy a diákok számára fontosak a döntési lehetöségek a tanulási folyamat személyre szabása érdekében. A tanári támogatással kapcsolatos eredmények egybevágnak az affektív-érzelmi tanulási tényezőkkel (Picard és mtsai, 2004), illetve az észlelt tanári kiégéssel kapcsolatos korábbi kutatási eredményekkel (Tatar és Yahav, 1999; Zhang és Sapp, 2009). Ez alapján a pedagógusi munka hatékonyabbá tétele során kiemelt szerepe lehet a tanár-diák kapcsolatok alakításának, ami a leterheltség észlelt mértékének csökkenését is segítheti. Mindemellett a személyes fejlődés lehetőségének szerepét érdemes kiemelni, mely szintén fontos erőforrásnak számít az eredmények alapján.

A motivációs jellemzőket tekintve alapvetően a külső ösztönzők túlsúlya rajzolódik ki a belső hajtóerőhöz képest. Ez abból a szempontból érthető, hogy a szakgimnáziumokban oktatott többféle tantárgy esetében változatos mértékben alakulhat ki érdeklődés a diákok részéről az egyes tárgyak iránt, így több esetben is a későbbi hasznosíthatóság, vagy az érdemjegyek szolgálhatnak motivációként.

A motivációs tényezők és a követelmény-erőforrás modell tényezői közötti együtt járások többnyire az előfeltevéseknek megfelelően alakultak. Első hipotézisünk szerint a követelmények és a motivációs alskálák között negatív kapcsolatot feltételeztünk, azonban az elemzés szerint nincs, vagy nagyon gyenge mértékü a változók közötti együtt járás. Ez a nem várt eredmény azt sugallja, hogy nem önmagukban a követelmények játszanak szerepet az esetleges motivációvesztésben, sokkal inkább az erőforrásokkal való együttes hatás, azaz a leterheltség hozható kapcsolatba a motiváció csökkenésével és közvetve a kiégéssel is.

Második hipotézisünk az erőforrások és a motiváció közötti pozitív kapcsolat megjelenését feltételezte. Ezt az eredmények egyértelmüen megerősítették, mind az intrinzik, mind az extrinzik motiváció esetében. Fontos kiemelni a belső motiváció és az erőforrások kapcsolatát. Úgy tűnik, hogy az erőforrások általánosságban kapcsolatban állnak a motivációs tényezőkkel, főként a személyes fejlődés lehetősége és a tanároktól érkező támogatás. Jóllehet a kontroll és a személyes fejlődés lehetősége az öndeterminációs

A követelmény-eróforrás modellben fontos szerepe van a leterheltség mutatónak, amely a követelmények és az erôforrások arányán alapuló érték. Negyedik hipotézisünkben feltételeztük, hogy a leterheltség mutató és az amotiváció között pozitív kapcsolat van. Eredményeink szerint a kapcsolat bár nem erốs, de egyértelmúen szignifikáns. A leterheltség mutató számitása nemcsak az amotivációval való kapcsolata miatt lényeges, de alapját képezheti intervenciós tevékenységek tervezésének is. A követelmények és az erốforrások aránya egyrészt rámutat arra, hogy a diákok közel 40\%-a érzékeli azt, hogy a követelmények kerülnek túlsúlyba az iskolával kapcsolatban. Mivel a leterheltség mutató negatív kapcsolatban áll a motivációs tényezókkel, ezért érdemes foglalkozni az eróforrások támogatásával, illetve a pszichológiai értelemben vett követelmények csökkentésével. 
elméletnek megfelelően együtt járt az intrinzik motivációval, azonban az autonómia és a motivációk között nem találtunk együtt járást, így harmadik hipotézisünket csak részben igazolták az eredmények. Mivel az erőforrások egy része szituációs tényező, ezért feltételezhető, hogy hatással lehetnek a motivációs tényezők alakulására. Ugyanakkor kizárólag a jelen vizsgálat korrelációs jellegéből fakadóan ez a hatás nem jelenthető ki egyértelmüen, további felmérések szükségesek a tényezők közötti kapcsolat mélyebb megértéséhez. Azonban ha a feltételezés beigazolódik, abból levonható az a következtetés, hogy az erőforrások elérhetőbbé válása esetén megerősíthető a motiváció, ami a későbbi intervenciós módszerek alapjául szolgálhat.

A követelmény-erőforrás modellben fontos szerepe van a leterheltség mutatónak, amely a követelmények és az erőforrások arányán alapuló érték. Negyedik hipotézisünkben feltételeztük, hogy a leterheltség mutató és az amotiváció között pozitív kapcsolat van. Eredményeink szerint a kapcsolat bár nem erős, de egyértelmüen szignifikáns. A leterheltség mutató számítása nemcsak az amotivációval való kapcsolata miatt lényeges, de alapját képezheti intervenciós tevékenységek tervezésének is. A követelmények és az erőforrások aránya egyrészt rámutat arra, hogy a diákok közel $40 \%$-a érzékeli azt, hogy a követelmények kerülnek túlsúlyba az iskolával kapcsolatban. Mivel a leterheltség mutató negatív kapcsolatban áll a motivációs tényezőkkel, ezért érdemes foglalkozni az erőforrások támogatásával, illetve a pszichológiai értelemben vett követelmények csökkentésével. Ez főként arra való tekintettel lehet fontos célkitüzés, hogy a leterheltség kapcsolata erősebb a motivációs tényezőkkel, mint önmagukban a követelményeké.

\section{Limitációk}

A kutatás eredményei mellett érdemes megemlíteni azokat a korlátozó tényezőket, amelyeket figyelembe véve mélyebben megérthetők a vizsgálat tanulságai. Egyrészt a minta összetételére vonatkozóan tehetők észrevételek. A kutatás résztvevői között kizárólag szakgimnáziumi tanulók voltak, így a gimnáziumi és szakközépiskolai képzésekre vonatkozó leterheltségi vizsgálatok a meglévő eredmények fontos kiegészítését jelenthetik a jövőben. Emellett pedig az elemszám bővítése is lényeges lehet, hogy általánosíthatóbb következtetéseket vonhassunk le. Továbbá fontos lenne longitudinális vizsgálati elrendezés segítségével elemezni a leterheltséghez hozzájáruló tényezőket. Ez egyrészt a mérőeszköz idői stabilitásának ellenőrzéséhez is fontos lehet, másrészt pedig elképzelhető, hogy a tanév különböző szakaszaiban máshogyan érzékelik ugyanazokat a tényezőket a diákok. Feltehetően a tanév elején kevésbé éreztetik hatásukat a követelmények, míg a tanév közepén-végén a hosszú távú leterheltség hatása felerősödhet.

\section{Összefoglalás}

Összességében az eredmények rámutatnak arra, hogy az iskolai környezetben számos olyan nem anyagi jellegü erőforrás található, amely hozzájárulhat a diákok jóllétének kialakulásához, és amelyek kapcsolatban állnak a motivációs tényezőkkel. Ez azért tekinthető fontosnak, mert a pedagógiai helyzetek megváltoztatásával elérhetőbbé válnak az olyan erőforrások, mint a tanárok támogatása és visszajelzései, a kontroll és az autonómia biztosítása a diákoknak a döntési lehetőségek által, vagy a személyes fejlődés lehetösége. 


\section{Irodalom}

Altintas, E., Karaca, Y., Moustafa, A. \& El Haj, M. (2020). Effect of Best Possible Self Intervention on Situational Motivation and Commitment in Academic Context. Learning and Motivation, 69. DOI: 10.1016/j.lmot.2019.101599

Areepattamannil, S., Freeman, J. G. \& Klinger, D. A. (2011). Intrinsic motivation, extrinsic motivation, and academic achievement among Indian adolescents in Canada and India. Social Psychology of Education, 14(3), 427-439. DOI: 10.1007/s11218-011-9155-1

Bakker, A. B. \& Demerouti, E. (2017). Job demandsresources theory: Taking stock and looking forward. Journal of Occupational Health Psychology, 22(3), 273-285. DOI: 10.1037/ocp0000056

Bakker, A. B., Hakanen, J. J., Demerouti, E. \& Xanthopoulou, D. (2007). Job resources boost work engagement, particularly when job demands are high. Journal of Educational Psychology, 99(2), 274-284. DOI: 10.1037/0022-0663.99.2.274

Bask, M. \& Salmela-Aro, K. (2013). Burned out to drop out: Exploring the relationship between school burnout and school dropout. European Journal of Psychology of Education, 28(2), 511-528. DOI: 10.1007/s10212-012-0126-5

Bolkan, S. (2015). Intellectually Stimulating Students' Intrinsic Motivation: The Mediating Influence of Affective Learning and Student Engagement. Communication Reports, 28(2), 80-91. DOI: 10.1080/08934215.2014.962752

Bottiani, J. H., Duran, C. A. K., Pas, E. T. \& Bradshaw, C. P. (2019). Teacher stress and burnout in urban middle schools: Associations with job demands, resources, and effective classroom practices. Journal of School Psychology, 77, 36-51. DOI: 10.1016/j.jsp.2019.10.002

Brookover, W. B., Schweitzer, J. H., Schneider, J. M., Beady, C. H., Flood, P. K. \& Wisenbaker, J. M. (1978). Elementary School Social Climate and School Achievement. American Educational Research Journal, 15(2), 301-318. DOI: 10.3102/00028312015002301

Brouwers, A., Tomic, W. \& Boluijt, H. (2011). Job demands, job control, social support and self-efficacy beliefs as determinants of burnout among physical education teachers. Europe's Journal of Psychology, 7(1), 17-39. DOI: 10.5964/ejop.v7i1.103

Burnett, P. C. \& Fanshawe, J. P. (1997). Measuring School-Related Stressors in Adolescents. Journal of Youth and Adolescence, 26(4), 415-428. DOI: 10.1023/a:1024529321194

Cilliers, J. R., Mostert, K. \& Nel, J. A. (2017). Study demands, study resources and the role of personality characteristics in predicting the engagement of fist-year university students. South African Journal of Higher Education, 32(1). DOI: 10.20853/32-1-1575

Deci, E. L. \& Ryan, R. M. (1985). Intrinsic Motivation and Self-Determination in Human Behavior. Springer US. DOI: 10.1007/978-1-4899-2271-7

Deci, E. L. \& Ryan, R. M. (2000). The „What” and "Why" of Goal Pursuits: Human Needs and the Self-Determination of Behavior. Psychological Inquiry, 11(4), 227-268. DOI: 10.1207/ s15327965pli1104_01

Demerouti, E., Bakker, A. B., Nachreiner, F. \& Schaufeli, W. B. (2001). The job demands-resources model of burnout. Journal of Applied Psychology, 86(3), 499-512. DOI: 10.1037/0021-9010.86.3.499

Dicke, T., Stebner, F., Linninger, C., Kunter, M. \& Leutner, D. (2018). A longitudinal study of teachers' occupational well-being: Applying the job demands-resources model. Journal of Occupational Health Psychology, 23(2), 262-277. DOI: 10.1037/ ocp0000070

Dobozy Gyöngyi (2015). A diákok mindennapjai, a tanulói munkaterhek vizsgálata az érettségi elötti és utáni 2-2 évfolyamon. Opus et Educatio, 2(3), 123-134. DOI: 10.3311/ope.60

Eccles, J. S., Wigfield, A., Midgley, C., Reuman, D., Iver, D. M. \& Feldlaufer, H. (1993). Negative Effects of Traditional Middle Schools on Students' Motivation. The Elementary School Journal, 93(5), 553-574. DOI: 10.1086/461740

Evers, W. J. G., Tomic, W. \& Brouwers, A. (2004). Burnout among Teachers: Students' and Teachers' Perceptions Compared. School Psychology International, 25(2), 131-148. DOI: 10.1177/0143034304043670

Fiorilli, C., De Stasio, S., Di Chiacchio, C., Pepe, A. \& Salmela-Aro, K. (2017). School burnout, depressive symptoms and engagement: Their combined effect on student achievement. International Journal of Educational Research, 84, 1-12. DOI: 10.1016/j. ijer.2017.04.001

Folkman, S., Lazarus, R. S., Gruen, R. J. \& DeLongis, A. (1986). Appraisal, coping, health status, and psychological symptoms. Journal of Personality and Social Psychology, 50(3), 571-579. DOI: 10.1037/0022-3514.50.3.571

Freudenberger, H. J. (1974). Staff Burn-Out. Journal of Social Issues, 30(1), 159-165. DOI: 10.1111/ j.1540-4560.1974.tb00706.x

Gaffney, H., Ttofi, M. M. \& Farrington, D. P. (2019). Evaluating the effectiveness of school-bullying prevention programs: An updated meta-analytical review. Aggression and Violent Behavior, 45, 111133. DOI: $10.1016 /$ j.avb.2018.07.001 
Gao, S., Yang, M., Wang, X., Min, W. \& Rozelle, S. (2019). Peer relations and dropout behavior: Evidence from junior high school students in northwest rural China. International Journal of Educational Development, 65, 134-143. DOI: 10.1016/j. ijedudev.2018.04.001

Garon-Carrier, G., Boivin, M., Guay, F., Kovas, Y., Dionne, G., Lemelin, J.-P., Séguin, J. R., Vitaro, F. \& Tremblay, R. E. (2016). Intrinsic Motivation and Achievement in Mathematics in Elementary School: A Longitudinal Investigation of Their Association. Child Development, 87(1), 165-175. DOI: 10.1111/ cdev. 12458

Ghasemi, A. \& Zahediasl, S. (2012). Normality Tests for Statistical Analysis: A Guide for Non-Statisticians. International Journal of Endocrinology and Metabolism, 10(2), 486-489. DOI: 10.5812/ijem.3505

Henry, K. L., Knight, K. E. \& Thornberry, T. P. (2012). School Disengagement as a Predictor of Dropout, Delinquency, and Problem Substance Use During Adolescence and Early Adulthood. Journal of Youth and Adolescence, 41(2), 156-166. DOI: 10.1007/s10964-011-9665-3

Hodge, B., Wright, B. \& Bennett, P. (2019). Increasing student engagement and reducing exhaustion through the provision of demanding but well-resourced training. Journal of Further and Higher Education, 43(3), 406-417. DOI: 10.1080/0309877x.2017.1363385

Huebner, E. S., Gilman, R. \& Laughlin, J. E. (1999). A Multimethod Investigation of the Multidimensionality of Children's Well-Being Reports: Discriminant Validity of Life Satisfaction and Self-Esteem. Social Indicators Research, 46(1), 1-22. DOI: 10.1023/a:1006821510832

Inchley, J., Currie, D., Young, T., Samdal, O., Torsheim, T., Augustson, L., Mathison, F., Aleman-Diaz, A., Molcho, M., Weber, M. \& Barnekow, V. (2016). Growing up unequal: Gender and socioeconomic differences in young people's health and well-being. Health Behaviour in School-aged Children (HBSC) study: International report from the 2013/2014 survey. (Health Policy for Children and Adolescents, No. 7). WHO Regional Office for Europe. http://www. euro.who.int/en/publications/abstracts/growing-upunequal.-hbsc-2016-study-20132014-survey

Jagodics Balázs, Nagy K., Szénási Sz., Varga R. \& Szabó Éva (megjelenés alatt). Az iskolai leterheltség és kiégés vizsgálata a követelmény-erőforrás modell segítségével magyar általános iskolások körében. Alkalmazott Pszichológia.

Jagodics, B. \& Szabó, É. (2014). Job demands versus resources: Workplace factors related to teacher burnout. Practice and Theory in Systems of Education, 9(4), 377-390.

Kain, J. \& Jex, S. (2010). Karasek's (1979) job demands-control model: A summary of current issues and recommendations for future research. In Perrewé, P. L. \& Ganster, D. C. (szerk.), Research in Occupational Stress and Well-being. 8. kötet. Emerald Group Publishing Limited. 237-268. DOI: 10.1108/s1479-3555(2010)0000008009

Karasek, R. A. (1979). Job demand, job decision latitude, and mental strain: Implications for job redesign. Administrative Science Quarterly, 24, 285-309. DOI: $10.2307 / 2392498$

Kember, D. (2004). Interpreting student workload and the factors which shape students' perceptions of their workload. Studies in Higher Education, 29(2), 165-184. DOI: 10.1080/0307507042000190778

Konu, A. (2002). Well-being in schools: A conceptual model. Health Promotion International, 17(1), 79-87. DOI: 10.1093/heapro/17.1.79

Konu, A. I., Lintonen, T. P. \& Autio, V. J. (2002). Evaluation of Well-Being in Schools ? A Multilevel Analysis of General Subjective Well-Being. School Effectiveness and School Improvement, 13(2), 187200. DOI: 10.1076/sesi.13.2.187.3432

Kyndt, E., Dochy, F., Struyven, K. \& Cascallar, E. (2011). The direct and indirect effect of motivation for learning on students' approaches to learning through the perceptions of workload and task complexity. Higher Education Research \& Development, 30(2), 135-150. DOI: 10.1080/07294360.2010.501329

Lazarus, R. S. \& Folkman, S. (1984). Stress, apprais$a l$, and coping. Springer.

Lee, Y. J. \& Anderman, E. M. (2020). Profiles of perfectionism and their relations to educational outcomes in college students: The moderating role of achievement goals. Learning and Individual Differences. DOI: 10.1016/j.lindif.2019.101813

Long, J. F., Monoi, S., Harper, B., Knoblauch, D. \& Murphy, P. K. (2007). Academic Motivation and Achievement Among Urban Adolescents. Urban Education, 42(3), 196-222. DOI: 10.1177/0042085907300447

Maslach, C., Schaufeli, W. B. \& Leiter, M. P. (2001). Job Burnout. Annual Review of Psychology, 52(1), 397-422. DOI: 10.1146/annurev.psych.52.1.397

Mayer József (2003). A tanulók munkaterheiről. Ú $j$ Pedagógiai Szemle, 53(7-8), 70-87.

OECD. (2019). PISA 2018 Results (Volume III): What School Life Means for Students' Lives. OECD. DOI: 10.1787/acd78851-en

Oktatáskutató és Fejlesztő Intézet. (2019a). Kerettanterv a szakközépiskolák 9-12. Évfolyamára. http://kerettanterv.ofi.hu/06_melleklet_9-12_szki/ index szakkozep.html

Oktatáskutató és Fejlesztő Intézet. (2019b). Kerettanterv az általános iskola 5-8. Évfolyamára. http:/ kerettanterv.ofi.hu/02 melleklet 5-8/index_alt isk felso.html

Ouweneel, E., Le Blanc, P. M. \& Schaufeli, W. B. (2011). Flourishing students: A longitudinal study 
on positive emotions, personal resources, and study engagement. The Journal of Positive Psychology, 6(2), 142-153. DOI: 10.1080/17439760.2011.558847

Picard, R. W., Papert, S., Bender, W., Blumberg, B., Breazeal, C., Cavallo, D., Machover, T., Resnick, M., Roy, D. \& Strohecker, C. (2004). Affective Learning - A Manifesto. BT Technology Journal, 22(4), 253-269. DOI: 10.1023/b:bttj.0000047603.37042.33

Salmela-Aro, K., Kiuru, N., Leskinen, E. \& Nurmi, J.-E. (2009). School Burnout Inventory (SBI): Reliability and Validity. European Journal of Psychological Assessment, 25(1), 48-57. DOI: 10.1027/10155759.25.1.48

Salmela-Aro, K. \& Upadyaya, K. (2014). School burnout and engagement in the context of demands-resources model. British Journal of Educational Psychology, 84(1), 137-151. DOI: 10.1111/bjep.12018

Salmivalli, I. \& Voeten, M. (2004). Connections between attitudes, group norms, and behaviour in bullying situations. International Journal of Behavioral Development, 28(3), 246-258. DOI: $10.1080 / 01650250344000488$

Schiffinger, M. \& Braun, S. M. (2019). The impact of social and temporal job demands and resources on emotional exhaustion and turnover intention among flight attendants. Journal of Human Resources in Hospitality \& Tourism, 1-24. DOI: 10.1080/15332845.2020.1702867

Sorkkila, M., Tolvanen, A., Aunola, K. \& Ryba, T. V. (2019). The role of resilience in student-athletes' sport and school burnout and dropout: A longitudinal person-oriented study. Scandinavian Journal of Medicine \& Science in Sports, sms.13422. DOI: 10.1111/ sms. 13422

Szabó Éva \& Jagodics Balázs (2016). Erőforrások és követelmények. Iskolakultúra, 26(11). DOI: 10.17543/iskkult.2016.11.3
Tatar, M. \& Yahav, V. (1999). Secondary school pupils' perceptions of burnout among teachers. British Journal of Educational Psychology, 69(4), 457-468. DOI: 10.1348/000709999157824

Thapa, A., Cohen, J., Guffey, S. \& Higgins-D’Alessandro, A. (2013). A Review of School Climate Research. Review of Educational Research, 83(3), 357-385. DOI: 10.3102/0034654313483907

The Jamovi Project. (2019). Jamovi. https://www. jamovi.org

Tóth-Király, I., Orosz, G., Dombi, E., Jagodics, B., Farkas, D. \& Amoura, C. (2017). Cross-cultural comparative examination of the Academic Motivation Scale using exploratory structural equation modeling. Personality and Individual Differences, 106, 130-135. DOI: 10.1016/j.paid.2016.10.048

Vallerand, R. J., Pelletier, L. G., Blais, M. R., Briere, N. M., Senecal, C. \& Vallieres, E. F. (1992). The Academic Motivation Scale: A Measure of Intrinsic, Extrinsic, and Amotivation in Education. Educational and Psychological Measurement, 52(4), 1003-1017. DOI: $10.1177 / 0013164492052004025$

Várnai Dóra Eszter, Jármi Éva, Arnold Petra, Demetrovizs Zsolt, Németh Ágnes, Kökönyei Gyöngyi \& Örkényi Ágota (2018). A kortársbántalmazás (bullying) értelmezésének vizsgálata kvalitatív módszerrel - „Az iskoláskorú gyermekek egészségmagatartása” (HBSC) vizsgálat módszertanának kiegészítésére. Magyar Pszichológiai Szemle, 73(4), 519-539. DOI: 10.1556/0016.2018.73.4.1

Wolters, C. A., Yu, S. L. \& Pintrich, P. R. (1996). The relation between goal orientation and students' motivational beliefs and self-regulated learning. Learning and Individual Differences, 8(3), 211-238. DOI: 10.1016/s1041-6080(96)90015-1

Zhang, Q. \& Sapp, D. A. (2009). The Effect of Perceived Teacher Burnout on Credibility. Communication Research Reports, 26(1), 87-90. DOI: 10.1080/08824090802637122

\section{Absztrakt}

A diákok iskolai leterheltsége sokat kutatott terület, amelyet leggyakrabban az óraszámokkal és a tanulmányokhoz kapcsolódó feladatok mennyiségével kapcsolatban tárgyalnak. Egy másik szempontú megközelítést jelent a diákok pszichológiai értelemben vett leterheltségének vizsgálata, amelyhez elméleti keretként jelen kutatásban a követelmény-erőforrás modellt alkalmaztuk (Demerouti és mtsai, 2001). Ez a keretrendszer képes megragadni a leterheltséghez hozzájáruló tényezőket, például a negatív érzelmeket és a mentális megterhelést, illetve az azok ellen ható erőforrásokat (pl. tanárok támogatása, kontroll és személyes fejlődés lehetősége). A kérdöíves vizsgálatban 329 szakgimnáziumi tanuló vett részt. Mérőeszközként az Iskolai Követelmény-Eröforrás Kérdöívet és a Tanulmányi Motiváció Kérdőívet alkalmaztuk. A korrelációelemzés eredményei szerint az erőforrások pozitív kapcsolatban állnak a belső és külső tanulmányi motivációval egyaránt. A követelmények a motivációs típusok közül egyedül az amotivációval mutattak együtt járást. A követelmények és erőforrások különbségeként meghatározott leterheltség pontszáma pedig negatív kapcsolatban állt a motivációval.

A kutatás eredményei fontos hozzájárulást jelenthetnek a diákokat érő pszichológiai hatások megértésében. A statisztikai elemzések adatai szerint fontos szerepe lehet az erőforrások elérhetővé tételének a diákok leterheltségének csökkentésében, például a személyes fejlődés lehetőségének, a tanulásban megtapasztalt autonómia és kontroll kialakításával, illetve a szülői és tanári támogatás erősítésével. 